\title{
Ambiguities of Personhood, Citizenship, Migration and Fundamental Rights in EU Law
}

DANIEL THYM ${ }^{*}$

I. Introduction

Both 'personhood' and 'human rights' are basic categories of law with a long tradition in (Western) thought. Historically, not all human beings were considered equal persons before the law, although most jurisdictions in Europe moved towards the principled recognition of legal personality, within domestic legal orders at least, during the nineteenth century. Against this background, it does not come as a surprise that the human right to equal personhood before the law enshrined in Article 16 International Covenant on Civil and Political Rights and Article 6 Universal Declaration of Human Rights finds no equivalent in the European Convention on Human Rights and the EU Charter of Fundamental Rights and has little practical impact in the EU legal order. As an abstract category, the human right to legal personality may not have much relevance, although a reminder of historic debates in civil law jurisdictions shows striking similarities to contemporary debates about migration. From today's perspective, the delineation of fundamental rights and citizenship reveals a surprising conceptual ambiguity over the role of the individual underlying basic concepts of Union law.

This chapter will focus on the category of the right-bearer in terms of groups of subjects endowed with individual rights as a heuristic device to reconstruct different conceptions of personhood in Union law. This undertaking concentrates on fundamental rights of individuals in the EU Treaties covering both human rights sensu stricto and the classic guarantees to transnational free movement, which lie at the heart of the single market. Closer inspection shows that there

\footnotetext{
* Professor of Public, European and International Law and Managing Director of the Research Centre Immigration \& Asylum Law at the University of Konstanz.
} 
is no uniform category of the right-bearer in Union law and that subjects that may invoke fundamental guarantees changed over time. The argument will start with an explanation of the historical background of legal personhood and related human rights guarantees (see below II) and explore the status of the individual in EU law thereafter (see below III). On this basis, it will present what I call the 'citizenship-personhood-cleavage' defining the interplay between Union citizenship and rules on immigration and asylum together with a proposal of how to reconstruct the distinction from a constitutional perspective (see below IV).

\section{Personhood and Human Rights}

In international human rights law, legal personhood is considered a fundamental right enshrined in Article 16 International Covenant on Civil and Political Rights (ICCPR) and Article 6 Universal Declaration of Human Rights (UDHR) which both state: 'Everyone shall have the right to recognition everywhere as a person before the law'. Closer inspection of the historical and conceptual background explains why the guarantee has no equivalent at European level: it was considered self-evident. At the same time, the history of private law in the continental European tradition based on Roman law reveals that abstract notions, such as 'personhood', have mostly had a theoretical significance, while legal practice was primarily concerned with degrees of rights attached to a certain 'status' (see below A). This resonates with contemporary Union law where rights of individuals are multifaceted, although abstract debates on legal personality can be relevant in borderline scenarios, such as extraterritorial application or the definition of the beginning or termination of human life (see below B).

\section{A. Historical and Conceptual Background}

Historically, not all human beings were considered persons before the law. Roman law famously assumed that slaves were not persona and categorised them as res (objects) instead ${ }^{1}$ - mirroring the nineteenth century controversy about the constitutional status of slaves in the US. ${ }^{2}$ One should be careful, however, to not read too much into the use of the term 'person' in legal texts during antiquity and the Middle Ages, since it can be argued that Roman jurists employed the term without much legal substance and conceptual depth but as a rather mundane description

\footnotetext{
1 See S Drescher, 'Slavery' in B Fassbender and A Peters (eds), The Oxford Handbook of the History of International Law (Oxford, Oxford University Press, 2012) 890-916.

${ }^{2}$ cf US Supreme Court, Dred Scott $v$ Sandford [1857] 60 US 393 which, technically, concerned the notion of citizenship under Art III s 2(1) US Constitution.
} 
of a human being. ${ }^{3}$ If that was correct, Roman law should be remembered primarily for having focused on the status (or rather stati) ${ }^{4}$ of a person, thereby emphasising the potential for differentiation, for instance in relation to the status libertatis about degrees of slavery. ${ }^{5}$ This status-oriented approach was taken up by civil law jurisdictions to describe categories of legal relations between members of society such as different degrees of servitude among peasants in medieval Europe or the special status of Jews which complemented grades of personhood and legal capacity in the feudal system. ${ }^{6}$ In short, there seems to have been no deep concept of personhood, whose use rather mirrored the etymological origin of the term 'persona' designating theatrical masks for different roles or characters performed by an actor.

A more substantive concept of personhood, upon which today's understanding can be built, was developed during the early modern era by natural lawyers and moral philosophers. ${ }^{8}$ They advanced the abstract category of the 'person' as a self-reliant moral actor and legal subject that cannot be deprived of his character as a right-bearer inherent in any human being in their legal writing, ${ }^{9}$ while Immanuel Kant is probably the best-known champion of a philosophical notion of personhood..$^{10}$ Notwithstanding differences among the positions put forward and the context in which they were voiced, such approaches resonate with basic notions of human dignity which underlie contemporary conceptions of human rights as unalienable entitlements. ${ }^{11}$ Along these lines, this chapter refers to human

3 Arguably, the reconstruction of Roman legal materials by private lawyers during the 19th century in the tradition of the German historical school and the more positivist jurisprudence of concepts (Begriffsiurisprudenz) over-interpreted historical sources by applying their own methodological preconception; see H Coing, Europäisches Privatrecht, Bd 1. Älteres Gemeines Recht (1500-1800) (Munich, CH Beck, 1985) 167-68.

4 The use of the plural indicates that an individual could have different stati in Roman law, such as the famous distinction between the status libertatis, civitatis and familiae; see H Coing, Zur Geschichte des Privatrechtsystems (Frankfurt/Main, Klostermann, 1962) 195-224.

5 See Coing (n 3) 168-69.

6 See Coing (n 4) 204-19.

7 See M Mauss, 'Une catégorie de l'esprit humain: La notion de personne, celle de "moi"' (1938) 68 Journal of the Royal Anthropological Institute 263, 274-77.

${ }^{8}$ It remains disputed as to whether Greek and Roman philosophy had a clear concept of personhood; see S Moyn, 'Plural Cosmopolitanisms and the Origins of Human Rights' in C Douzinas and C Gearty (eds), The Meanings of Rights. The Philosophy and Social Theory of Human Rights (Cambridge, Cambridge University Press, 2014) 193, 193-97.

9 On early modern legal thinkers such as Súarez, Pufendorf or Wolff, see C Hattenhauer, "'Der Mensch als solcher ist rechtsfähig”-Von der Person zur Rechtsperson' in E Klein and C Menke (eds), Gewaltenteilung und Menschenrechte (Berlin, BWV, 2006) 39, 41-50; and M Lutz-Bachmann, 'Der Mensch als Person. Überlegungen zur Geschichte des Begriffs der "moralischen Person" und der Rechtsperson' in ibid 109, 114-17.

10 On Kant's notion of personhood, see G Mohr, 'Person, Recht und Menschenrecht bei Kant' in Klein and Menke (n 9) 17-38.

11 There is certainly no uniform idea about the theoretical foundation of human rights; on the plurality of positions, see JW Nickel, 'Human Rights' (2013) Stanford Encyclopedia of Philosophy, online at http://plato.stanford.edu/entries/rights-human. 
rights as norms to which all human beings are inherently entitled irrespective of nationality, legal status, etc, thereby defining their personhood. Such a simplified starting-point is sufficient for our legal analysis. ${ }^{12}$

Against the background of the history of civil law with its tradition of diverse statuses in Roman antiquity and medieval feudalism, we understand why it was not self-evident that the French code civil of 1804 emphasised that there should be equal personhood and civil rights for citizens and many foreigners ${ }^{13}$ mirroring similar provisions in other codifications at the time. ${ }^{14}$ Fifty years later, the mort civil, which continued the legal tradition of the 'outlaw' and entailed the loss of civil rights, was formally abolished in France and beyond. ${ }^{15}$ Hence, most European jurisdictions had moved towards the recognition of equal legal personhood by the end of the nineteenth century, ${ }^{16}$ although the distinctions between degrees of legal personhood were often retained in the colonies. ${ }^{17}$ By way of example section 1 Bürgerliches Gesetzbuch, the German civil code of 1 January 1990, stated paradigmatically: 'The legal personality of human beings begins with the completion of birth. ${ }^{18}$

Materials explaining the motivation for this formulation in the introductory provision of the German civil code, in the drafting of which academics played a prominent role, referred to the underlying moral standpoint:

By recognising the legal personality of each human being irrespective of its character and will, the legal order realises a commandment of reason and ethics. Besides this provision, the content of the code as a whole reflects this requirement of today's sense of right or wrong [Rechtsbewusstsein] as a self-evident statement. ${ }^{19}$

\footnotetext{
12 I understand the term 'fundamental rights' in the title, which has been assigned by the editors, to refer to 'human' and 'fundamental' rights interchangeably-mirroring Recital 2, 3 Preamble to the ECHR, which indicates that 'fundamental rights' (in the ECHR) are the legal embodiment of the concept of 'human rights' (in the UDHR); see T van Boven, 'Préambule' in LE Pettiti et al (eds), La Convention européenne des droits de l'homme 2nd edn (Paris, Economica, 2009) 125, 127; it also covers the free movement of persons in the EU single market conceived as a human rights by Art 45(1) EU Charter.

13 See the French Code civil, Part I, title 1, Arts 7-8 for citizens and Arts 11-16 for foreigners.

14 On the Prussian Allgemeine Landrecht of 1794, which employed a somewhat ambiguous formulation continuing the tradition of difference statuses in the definition of legal personhood, and the more Kantian Austrian Allgemeines Bürgerliches Gesetzbuch of 1811/12, see Hattenhauer (n 9) 52-58.

15 Article 25 Code civil (n 13) was abolished in 1854; similarly, the prescription in s 135 of the German Constitution of 1849 (which never entered into force) and corresponding rules in the constitutions of German states in the early 1850 s.

16 For a comparative overview, see J Schröder, 'Rechtsfähigkeit' in A Erler and E Kaufmann (eds), Handwörterbuch zur deutschen Rechtsgeschichte, vol 4 (Köln, Schmidt, 1990) column 290.

17 See S Mezzarda, 'Citizen and Subject. A Postcolonial Constitution for the European Union?' in MC Caloz-Tschopp and P Dasen (eds), Mondialisation, migration et droits de l'homme. Un nouveau paradigme pour la recherche et la citoyenneté, vol I (Brussels, Bruylant, 2007) 533-47; and L Obregón Tarazona, 'The Civilized and the Uncivilized' in Fassbender and Peters (n 1) 917-42.

${ }^{18}$ Own translation of the German original: 'Die Rechtsfähigkeit des Menschen beginnt mit der Vollendung der Geburt'.

19 Motiven zu dem Entwurfe eines Bürgerlichen Gesetzbuches für das Deutsche Reich, vol 1 (Berlin, Guttentag, 1888) 25 (own translation).
} 
That is not to say, crucially, that continental European civil law at the time was pervaded by notions of equality as we understand them today. ${ }^{20}$ Tellingly, practical jurisprudence never paid much attention to the provision and focused instead on more specific rules in civil law codifications which often mirrored the earlier distinction between the stati ascribed to a person in the tradition of Roman law by perpetuating, for example, a lesser degree of legal capacity for women. ${ }^{21}$

\section{B. International Human Rights Law}

Article 6 UDHR took up the basic concept of equal legal personhood in civil law codifications and guided the drafting of the legally binding guarantee in Article 16 ICCPR according to which everyone is recognised 'as a legal person before the law'. Similar to corresponding guarantees in continental codes, the provision is generally understood to guarantee legal personhood only, ie the aptitude to have rights and obligations - not full legal capacity to enter into legal obligations autonomously. ${ }^{22}$ As a result, limitations in legal capacity, in particular for women, which were widespread across Europe until recently and persist elsewhere, are not covered by the provision, although more specific human rights may apply instead. ${ }^{23}$ This limited doctrinal reach of the right to legal personality explains why the provision never gained much practical relevance. ${ }^{24}$ It does not appear, therefore, as a lacuna, from a doctrinal perspective at least, that the European Convention on Human Rights (ECHR) and the EU Charter do not contain similar guarantees. Article 16 ICCPR represents, like the invocation of human dignity, a remainder of the equal moral worth of all persons lying at the heart of contemporary conceptions of unalienable human rights guarantees.

Noting the limited practical relevance of the human right to legal personality does not mean that there are no conceptual or doctrinal difficulties in defining the scope of state obligations with a direct or indirect bearing on how personhood is constructed in legal discourses. A first set of uncertainties concerns borderline cases, such as the status of the handicapped, animals, corporations or cyborgs,

20 It should be recognised, however, that the civil law codifications adopted during the 19th century were important instruments of bourgeois emancipation overcoming the conventional constraints of feudal societies in semi-monarchic political systems, which persisted in many European countries (notably Germany).

21 See Hattenhauer (n 9) 59-65.

22 See M Nowak, CCPR Commentary 2nd edn (Strasbourg/Kehl, NP Engel, 2005) Art 16 paras 2-3.

23 See M Deshaires 'Article 16' in E Decaux (ed), Le Pacte international relatif aux droits civils et politiques (Paris, Economica, 2010) 377, 379; one may criticise, however, the distinction between legal personality and capacity as sanctioning an active, disproportionately male conception of human behaviour.

${ }^{24}$ An exception are some (but not all) decisions on forced disappearance; $c f$ Human Rights Committee, Kimouche et al v Algeria, Communication 1327/2004, CCPR/C/90/D/1328/2004 of 16 August 2007. 
which are a matter of controversy in legal and philosophical circles. ${ }^{25}$ A typical example is embryos on which there are intense constitutional debates across the world. ${ }^{26}$ This chapter will not discuss corresponding uncertainties. Similarly, it does not concern social realities in the field but rather focuses on rules and principles in Union law. That is not to say that there are no practical problems, but discussing them would overstretch the scope of this chapter.

It is inherent in the structure of international human rights law that the universal ambition of the guarantee, in Article 16 ICCPR, that legal personality shall be guaranteed 'everywhere' is limited by the essentially territorial reach of state authority and corresponding human rights obligations. ${ }^{27}$ States are obliged to respect human rights 'to everyone within their jurisdiction' (Article 1 ECHR) which suggest that people outside of the state jurisdiction lack an addressee for human rights claims. While US constitutional law has traditionally been reluctant to accept extraterritorial application, ${ }^{28}$ the ECtHR (European Court of Human Rights) has held ever since the 1990s that the High Contracting Parties may be responsible for extraterritorial state action, such as the (more or less) effective control exercised by the United Kingdom in Southern Iraq. ${ }^{29}$ However, even such a broad reading does not resolve all potential problems, since the application of the ECHR will usually be limited to scenarios of effective state control over territory or individual persons. By contrast, the ECtHR found that air bombardments do not meet the threshold of Article 1 ECHR and are not, therefore, subject to its jurisdiction. ${ }^{30}$ Given that the EU Charter does not contain a similar provision, one may argue that it has a broader scope, ${ }^{31}$ although such an extension would not undo the state-focused underpinning of human rights law and there would therefore always remain scenarios where no state can be held directly responsible. As in the case of embryos, a discussion of territorial limits of Union law would be a topic in itself but will not be pursued further in this chapter.

At a more abstract level, there has always been a debate as to whether the concept of legal personhood should be limited to a 'thin' formal guarantee or whether it should embrace a 'thick' reading including substantive rights and/or social realities on the ground. ${ }^{32}$ Critical legal scholars emphasise that formal

\footnotetext{
25 See N Naffine, 'Who Are Law’s Persons? From Cheshire Cats to Responsible Subjects' (2003) 66 Modern Law Review 346-67.

26 See the paper by Stephanie Hennette-Vauchez in this volume.

27 See Deshaires (n 23) 390-91.

28 See L Bosniak, 'Persons and Citizens in Constitutional Thought' (2010) 8 International Journal of Constitutional Law 9, 18-21 and GL Neuman, 'The Extraterritorial Constitution after Boumediene v Bush' (2009) 82 Southern California Law Review 259-90.

${ }^{29}$ cf ECtHR, judgment of 7 July 2011 (GC), No 55721/07, Al-Skeini et al $v$ the United Kingdom, paras 130-142; and S Miller, 'Revisiting Extraterritorial Jurisdiction' (2009) 20 European Journal of International Law 1223-46.

30 See ECtHR, Decision of 12 Dec 2001 (GC), No 52207/99, Banković et al v Belgium et al.

31 For a generous approach, see C Costello and V Moreno-Lax, 'The Extraterritorial Application of the EU Charter of Fundamental Rights' in Peers et al (eds), The EU Charter of Fundamental Rights. A Commentary (Munich/Oxford, CH Beck/Hart, 2014) 1657-84.

32 cf Nowak (n 22) margin nos 3-6.
} 
guarantees alone, such as Article 16 ICCPR or $\$ 1$ of the German civil code, may mask profound forms of economic and social domination and reflect stereotyped worldviews..$^{33}$ I will not delve into this discussion at this level of abstraction and suggest, alternatively, to analyse it from a different angle when distinguishing between human rights of every person and citizens' rights of some in EU law. To do so may be more promising for a content-oriented legal analysis such as the one pursued in this chapter. The abstract notion of 'legal personality' has a chameleon character: it is capable of sustaining different conceptions which can be unearthed by focusing on more specific rules.

One example illustrates the benefit of such a content-oriented analysis transcending abstract notions of legal personality. The situation of 'illegal migrants' residing in a country without a residence right has caused intense legal and political debates, among others in the United States where the Supreme Court found that illegal residents are 'persons' within the meaning of the Fourteenth amendment. ${ }^{34}$ Similarly, both the ECHR and the EU Charter apply to 'everyone' irrespective of nationality or residence status. In a famous line of case-law, the ECtHR holds that persons without a right to reside can rely upon the protection of 'private life' under Article $8 \mathrm{ECHR}$ in exceptional circumstances to legalise their illegal stay in order to protect 'the network of personal, social and economic relations that make up the private life of every human being. ${ }^{35}$ In addition, secondary EU legislation guarantees that illegal migrants are protected against mistreatment by the employer as a matter of principle. ${ }^{36}$ Many Member States also grant basic health care and education even if access to such statutory guarantees is often hindered by a 'chilling effect' when the fear of deportation may prevent irregular migrants from accessing public services in situations where they are technically available. ${ }^{37}$ This shows that it can be beneficial to pierce the veil of personhood and to concentrate on substantive provisions.

33 See L Bosniak, 'Human Rights within one State. Dilemmas of Personhood in Liberal Constitutional Thought' in B Dembour and T Kelly (eds), Are Human Rights for Migrants? (London, Routledge, 2012) 201, 207-08; and S Strasser, 'Rethinking Citizenship. Critical Encounters with Feminist, Multicultural and Transnational Concepts of Citizenship' in B Halsaa et al (eds), Remaking Citizenship in Multicultural Europe. Women's Movements, Gender and Diversity (Suffolk, Palgrave, 2012) 21-41.

34 See H Motomura, 'Who Belongs? Immigration Outside the Law and the Idea of Americans in Waiting' (2012) 2 University of California Irvine Law Review 359-79.

35 ECtHR, judgment of 9 Oct 2003, No 48321/99, Slivenko et al $v$ Latvia, para 96; for further detail, see D Thym, 'Residence as de facto Citizenship? Protection of Long-Term Residence under Article 8 ECHR' in R Rubio-Marin (ed), Human Rights and Immigration (Oxford, Oxford University Press, 2014) 106-44.

36 See Art 6 of Dir 2009/52/EC [2009] OJ L168/24.

37 See R Cholewinski, Study on Obstacles to Effective Access of Irregular Migrants to Minimum Social Rights (Strasbourg, Council of Europe Publishing, 2006). 


\section{The Individual in EU Law}

The story of the individual and human rights in EU law has often been told. It is well known that the doctrine of direct effect and the evolution of human rights as unwritten general principles of law by the ECJ (European Court of Justice) followed the primary motivation to guarantee the effective application of EU law by domestic courts. Nevertheless both concepts developed a life of their own by empowering individuals to promote their agenda via Union law, in particular in situations where the EU's objectives coincide with the interests of individuals (see below A). In order to identify the underlying conception of personhood, an inspection of the groupings of individuals endowed with individual rights in the EU Treaties reveals different categories of right-bearers whose contours changed over time (see below B). From today's perspective, the distinction between citizens and non-citizens presents in itself a pertinent classification of personhood in EU law, in particular when it comes to free movement and migration.

\section{A. Rights of Individuals and Human Rights}

One of the most significant judgments in the history of the EU legal order, Van Gend en Loos, concerned the concept of individual rights, since the ECJ found that the EU Treaties constituted a new legal order 'the subjects of which comprise not only Member States but also their nationals [French: ressortissants]' and that, therefore, Union law 'not only imposes obligations on individuals [particuliers] but is also intended to confer upon them rights which become part of their legal heritage. ${ }^{38}$ Re-reading the judgment from an analytical standpoint and in the light of the research question pursued in this chapter, one is bound to notice the textual and substantive ambiguity of the above-mentioned formulation, including in the French version, ${ }^{39}$ with its reference to nationals (instead of all persons) in the first passage and obligations as well as rights in the second quotation. This ambiguity arguably reflects the primary motivation of the Court to guarantee the effet utile by making use of individuals to police compliance with Union law: the individual was activated as an instrument in support of Union law. ${ }^{40}$

\footnotetext{
38 Case 26/62, Van Gend en Loos, EU:C:1963:1.

39 Remember that the English language version is a translation produced at the time of British accession, while the Court drafted the judgment in French and delivered it also in German, Italian and Dutch originally (the German language version refers to Einzelne, ie individuals, in the first reference instead of nationals).

${ }^{40}$ See B de Witte, 'Direct Effect, Primacy and the Nature of the Legal Order' in P Craig and G de Búrca (eds), The Evolution of EU Law 2nd edn (Oxford, Oxford University Press, 2011) 177, 183-89, 205-07; and JHH Weiler, 'Van Gend en Loos: The Individual as Subject and Object and the Dilemma of European Legitimacy’ (2014) 12 International Journal of Constitutional Law 94-103.
} 
This functional approach to individual rights as an instrument for law enforcement has often been criticised for privileging certain actors, in particular those representing economic interests, and for favouring 'negative' market integration to the detriment of 'positive' political integration. ${ }^{41}$ Having said this, it should be emphasised that the prominence of individual rights in EU law can develop a life of its own. The Court may have perceived of the individual primarily as an 'agent' supporting the effectiveness of EU law, but it thereby created 'actors' promoting their agenda via Union law. As a legal doctrine, the concept of individual rights now has repercussions far beyond the internal market where economic considerations can be largely irrelevant, not least since secondary legislation can have the same direct effect in domestic legal orders as Treaty provisions. ${ }^{42}$

The example of the Family Reunification Directive 2003/86/EC shows that individual rights can serve as a doctrinal justification for limits to state discretion in relation to charges and language tests. ${ }^{43}$ Observers with a pro-migrant outlook regularly emphasise this potential of individual rights as an instrument for promoting a pro-migrant agenda before the Court. ${ }^{44}$ Of course, this outcome is no foregone conclusion, not least since the scope of individual rights enshrined in secondary legislation ultimately depends upon the wording, general scheme and objective of the instrument in question whose contours are determined by the legislature. Indeed, there are more examples of the ECJ backtracking from its initial ambition in the field of family reunification in light of presumed legislative preferences. ${ }^{45}$ This reaffirms that the promotion of individual rights is no end in itself but supports the realisation of broader EU objectives, ${ }^{46}$ which, in the field of migration, do not necessarily follow the freedom-centred approach of the single market. ${ }^{47}$

A similar trajectory can be observed for fundamental rights. They were first used by the Court as unwritten general principles of law in an instrumental manner as a defensive shield against a challenge to the supremacy of Union law by the German

41 For a pronounced critique, see F Scharpf, 'The European Social Model: Coping with the Challenges of Legitimate Diversity' (2002) 40 Journal of Common Market Studies 645-70; and Weiler (n 40).

42 Treaty rules on free movement were crucial for 'negative' market integration, while provisions in secondary legislation often bolster 'positive' integration.

43 Case C-578/08 Chakroun, EU:C:2010:117, paras 41, 43 demonstrate how the doctrine of individual rights can result in 'individual-friendly' legal conclusions; similarly, on the need for an individual assessment in case of language tests Case C-153/14 K \& A, EU:C:2015:453, paras 54-60.

44 See J Bast, Aufenthaltsrecht und Migrationssteuerung (Tübingen, Mohr Siebeck, 2011) 101-11; and K Groenendijk, 'Recent Developments in EU Law on Migration' (2014) 16 European Journal of Migration and Law 313, 329-30.

45 See Case C-338/13 Noorzia, EU:C:2014:2092; and the critical comments by G Milios, 'Family Reunification for Third-Country Nationals' (2015) 17 European Journal of Migration and Law 127, 130-32.

46 For immigration and asylum, see K Hailbronner and D Thym, 'Constitutional Framework' in ibid (eds), EU Immigration and Asylum Law. Commentary 2nd edn (Munich/Oxford, CH Beck/Hart Publishing, 2016) ch 1 margin no 15.

47 See below IV.B. 
Constitutional Court. ${ }^{48}$ In practice, they never gained much prominence and constituted, on the whole, a corollary element of Community action during the 1970s, 1980s and 1990s. ${ }^{49}$ Again, this passive approach need not be the ultimate answer, since the entry into force of a legally binding Charter of Fundamental Rights seems to have enhanced the visibility and relevance of human rights. The number of preliminary references to the ECJ increased exponentially and so did the number of judgments exploring the potential of the Charter, ${ }^{50}$ including prominent cases such as data retention. ${ }^{51}$ That is not to say that the Court takes human rights seriously in most or all situations and there may be structural reasons as to why they are bound to remain second-order principles in EU law. ${ }^{52}$ All I say is that the function and relevance of individual and fundamental rights can change over time and alter its meaning.

Institutional mechanisms ensuring compliance are central for the effective application of individual and human rights, both in instances of individual wrongdoing or systemic failure (like in the case of the Greek asylum system). ${ }^{53}$ The significance of institutional mechanisms is amplified when we accept that debates on human rights are not just about questions of doctrinal interpretation but relate to basic choices of societies which change over time. ${ }^{54}$ Against this background, another historical starting-point of individual rights in EU law deserves our attention, since the original EEC Treaty explicitly referred to 'persons' not only with regard to free movement, but also for judicial review regarding direct access to the Court in scenarios of direct and individual concern. ${ }^{55}$ It is well known that this right to standing has been interpreted narrowly by judges in Luxembourg ever since the Plaumann ruling of 1963 delivered a few weeks after Van Gend en Loos, ${ }^{56}$ since the federal structure of the Union entrusts Member States with the provision of procedural guarantees for effective judicial review. ${ }^{57}$

This solution may well be correct, since it reflects the broader constitutional set-up of the European Union-even though it underlines, for the purposes of

\footnotetext{
48 cf Case 11/70 Internationale Handelsgesellschaft, EU:C:1970:114, paras 3-4.

49 See M Dani, 'Constitutionalism and Dissonances' (2009) 15 European Law Journal 324, 329-35; and the classic account by P Alston and JHH Weiler, 'An "Ever Closer Union" in Need of a Human Rights Policy' in ibid (eds), The EU and Human Rights (Oxford, Oxford University Press, 1999) 3-66.

50 See the quantitative account in the Staff Working Document attached to the Commission's 2014 Report on the application of the Charter, SWD(2015) 99 of 8 May 2015, 7-11; and the qualitative analysis of court judgments by S Iglesias Sánchez, 'The Court and the Charter' (2012) 49 Common Market Law Review 1565-612.

51 cf Cases C-293/12 \& C-594/12, Digital Rights Ireland, EU:C:2014:238.

52 See the chapter by Damian Chalmers in this volume.

53 cf Cases C-411/10 \& C-493/10, NS et al, EU:C:2011:865.

54 See below s IV.

55 cf Art 173(2) EEC Treaty as established by the Treaty of Rome in line with today's Art 263(4) TFEU, which was broadened a little by the Treaty of Lisbon.

56 of Case 25/62 Plaumann v Commission, EU:C:1963:17; recently confirmed by Case C-583/11 P Inuit Tapiriit Kanatami et al v Parliament \& Council, EU:C:2013:625.

57 See Case C-50/00 P Unión de Pequeños Agricultores v Council, EU:C:2002:462, paras 40-41.
} 
our analysis, that the doctrines of direct effect and individual rights are primarily concerned with establishing effective government structures by supporting the effet utile of Union law. ${ }^{58}$ Individuals benefit from this approach when their interests coincide with the objectives pursued by the supranational legal order and corresponding doctrines of individual and human rights can unfold a certain dynamism promoting individual rights irrespective of EU objectives. However, this does not undo the rationale underlying their establishment and continued application.

\section{B. 'Personhood' in the Text of the EU Treaties}

To say that individuals can invoke guarantees under Union law does not explain which individuals benefit in practice and whether there are certain patterns discernible in the deep structure of the supranational legal order. This sub-section explores the evolution of the Treaty texts by focusing on the category of the rightbearer, subjects endowed with individual rights by the EU Treaties, as a heuristic device to re-construct different conceptions of personhood in Union law. Doing so leads us to the identification of what I will call the 'citizenship-foreigner-cleavage' in contemporary Union law discussed in the next section.

The original Treaty text contained little reference to abstract notions of personhood and/or human rights. ${ }^{59}$ The Treaty of Rome rather ensured the 'free movement of persons' (Title III), which literally embraced 'workers' (Article 48), 'nationals of a Member State' (Articles 52, 59), 'companies or firms' (Article 58), and allowed 'any natural or legal person' to initiate infringement proceedings (Article 173). While the latter provision had little relevance, it is well known among experts of EU law that the free movement of persons soon emerged as an essential guarantee whose effective implementation was promoted by the Commission and the Court. Notwithstanding the essentially economic rationale underlying the Treaty text, the 'market citizen', a term coined by Hans-Peter Ipsen to describe a status in between alienage and nationality, ${ }^{60}$ was never supposed to be a factor of production only. Implementing legislation adopted during the $1960 \mathrm{~s}^{61}$ and ECJ

58 See for the original approach in the early 1960s A Vauchez, 'The Transnational Politics of Judicialization. Van Gend en Loos and the Making of EU Polity' (2010) 16 European Law Journal 1, 3-4; and more generally D Chalmers and L Barroso, 'What van Gend en Loos Stands for' (2014) 12 International Journal of Constitutional Law 105, 120-33.

59 The 1951 Treaty establishing the Coal and Steel Community referred to 'person/ne(s)' or 'personnalité' (remember that only the French language version was authentic) mainly with regard to institutional questions, such as nomination as a judge.

60 See HP Ipsen, Europäisches Gemeinschaftsrecht (Tübingen, Mohr Siebeck, 1972) 250-54.

61 See D Thym, 'Family as Link. Explaining the Judicial Change of Direction on Residence Rights of Family Members from Third States' in H Verschueren (ed), Where Do I Belong? EU Law and Adjudication on the Link between Individuals and Member States (Antwerp, Intersentia, 2016) sect 2 (forthcoming). 
case-law from the 1970s onwards, involved elements one could describe as an incipient form of European citizenship with the Union legal order embracing the individual as a source of potential legitimacy. ${ }^{62}$

In the early 1970s, a debate emerged whether the abstract notion of 'worker' in the Treaty text may include those without the nationality of an EU Member State. ${ }^{63}$ The idea was rejected by the ECJ, ${ }^{64}$ but the argument is still occasionally taken up today when Community institutions are accused of 'revisionist interpretation' ${ }^{65}$ Historically, this accusation is inaccurate. Closer inspection of the drafting history shows that there was agreement during Treaty negotiations that only nationals should be covered: an explicit nationality clause fell 'victim' to Franco-Italian dispute about Algeria and German concerns about East Germans. ${ }^{66}$ Furthermore, the alleged parallelism with the free movement of goods is misleading, since the Common Commercial Policy does not cover migration law for persons. ${ }^{67}$ Of course, it would have been possible to reconceptualise the meaning of the Treaty texts and to extend the free movement of workers to foreigners by means of dynamic interpretation irrespective of the will of the founders. ${ }^{68}$ Yet, the political debate moved in a different direction.

In 1992, the Treaty of Maastricht officially transcended the economic rationale underlying the single market. Mirroring the original motivation for a united Europe in the Schuman declaration, the Treaty of Maastricht endeavoured to establish something like a political union. In terms of the reform steps brought forward, the introduction of 'Union citizenship' and the third pillar on justice and home affairs were among the most visible innovations. For our purposes, it is worth noting that two new categories of persons were introduced as a result of

${ }^{62}$ For controversial debates about early judgments on both workers and service recipients, see A Evans, 'European Citizenship' (1982) 45 Modern Law Review 497, 502-10; and the contemporary critique by JHH Weiler, 'Deciphering the Political and Legal DNA of European Integration: An Exploratory Essay' in J Dickson and P Eleftheriadis (eds), European Union Law (Oxford, Oxford University Press, 2012) 137, 151-55.

63 cf WR Böhning, 'The Scope of the EEC System of Free Movement of Workers: A Rejoinder' (1973) 10 Common Market Law Review 81-84; the freedom of establishment and to provide services were limited to nationals of EU Member States explicitly.

64 Those without an EU passport can benefit from the fundamental freedoms indirectly only, as family members by means of a legal reflex as 'derived rights'; cf Case C-256/11 Dereci et al, EU:C:2011:734, para 55.

65 E Guild and S Peers, 'Out of the Ghetto?' in S Peers and N Rogers (eds), EU Immigration and Asylum Law. Text and Commentary (The Hague, Martinus Nijhoff, 2006) 81, 114.

66 See S Goedings, Labor Migration in an Integrating Europe (The Hague, SDU Uitgevers, 2005) 128-35 who shows that the formulation of the nationality clause was delegated to a working group on oversea countries and territories, which seems to have forgotten the issue during heavy controversies on other issues.

67 The free movement of goods from third countries requires prior access to the single market in line with today's Art 28(2) TFEU; to this date, Art 34 TFEU does not cover restrictions to imports into the single market.

68 See D Kochenov and R Plender, 'EU Citizenship: From an Incipient Form to an Incipient Substance? The Discovery of the Treaty Text' (2012) 37 EL Rev 369-96. 
these reform steps. In 1992, the introduction of 'Union citizenship' ${ }^{69}$ for those holding a passport of an EU Member State and specific rules for 'nationals of third countries' ${ }^{70}$ within the intergovernmental pillar on justice and home affairs policy, were parallel phenomena. ${ }^{71}$ Since, in parallel, the fundamental freedoms were re-conceptualised as a specific expression of Union citizenship, the most famous individual rights at Treaty level became at that moment citizens' rights.

The introduction of Union citizenship by the Treaty of Maastricht may have been a spontaneous decision during the intergovernmental conference, ${ }^{72}$ but it built on more than a decade of political debates about a relance européenne ever since the mid-1970s when heads of state or government had promoted further integration under the heading of 'A Citizens' Europe ${ }^{\text {'73 }}$ through a collection of diverse policies including free movement for others beyond workers, direct elections of the European Parliament and the establishment of a passport union which later became the Schengen area. ${ }^{74}$ While the initial reception of Union citizenship was tempered at best, ${ }^{75}$ it is well known that the concept gained considerable prominence after 1999 in a series of ECJ judgments which constitute one of the most fascinating legal developments in recent memory ${ }^{76}$-although the Court seems to have retreated from its initial ambition lately. ${ }^{77}$

The Treaty of Lisbon, which replaced the erstwhile Constitutional Treaty, reaffirmed the direction taken in Maastricht. First, it buttressed citizens' rights through a discernible effort to replicate civic-republican participation at EU level by enhancing political dialogue, inter alia through the introduction of the citizens' initiative, and by declaring that the Union 'shall be founded on representative democracy'. ${ }^{78}$ Secondly, it established migration law towards third-country nationals as a policy field in its own right when it replaced the intergovernmental former third pillar with a fully 'supranationalised' policy design within the area of

69 Art 8 EC Treaty as amended by the Treaty of Maastricht [1992] OJ C224/36.

70 Art K.1 EU Treaty as established by the Treaty of Maastricht [1992] OJ C191/1.

71 See K Groenendijk, 'Categorizing Human Beings in EU Migration Law' in S Bonjour et al (eds), The Others in Europe (Brussels, Institut d'études européennes, 2011) 21-36.

72 Apparently, the Spanish Prime Minister Felipe González Márquez had the idea first; see F Wollenschläger, Grundfreiheit ohne Markt (Tübingen, Mohr Siebeck, 2007) 110-13.

73 L Tindemans, European Union, Report to the European Council, Bulletin of the European Communities Supplement 1/76, 26.

${ }^{74}$ See A Wiener, Building Institutions (Boulder, Westview, 1998) chs 2-3; and W Maas, Creating European Citizens (Lanham, Rowman \& Littlefield, 2007) ch 2.

75 See S O'Leary, The Evolving Concept of Community Citizenship (The Hague, Kluwer Law International, 1996) 304-07.

76 For an overview, see D Kochenov, 'The Essence of EU Citizenship Emerging from the Last Ten Years of Academic Debate' (2013) 62 International and Comparative Law Quarterly 97-136.

77 See D Thym, 'When Union Citizens turn into Illegal Migrants: the Dano case' (2015) 40 EL Rev 248, 259-60.

${ }^{78}$ Arts 9-11 TEU sound more ambiguous than the substance; $c f$ J Shaw, 'Citizenship' in Craig and de Búrca (n 40) 575, 605-08; and N Nic Shuibhne, 'The Resilience of EU Market Citizenship' (2010) 47 Common Market Law Review 1597, 1619-27. 
freedom, security and justice. At the same time, the Charter became legally binding and declared that the Union 'places the individual at the heart of its activities, by establishing the citizenship of the Union and by creating an area of freedom, security and justice. ${ }^{79}$ This raises the following question: how does one explain the apparent cleavage between citizens' rights and migration law in the EU Treaties, which was indicated first by the parallel introduction of the terms 'Union citizenship' and 'third-country national' and came full circle with the reinforcement of corresponding sets of rules in the Treaty of Lisbon?

\section{The Citizenship-Foreigner-Cleavage}

Legal analyses should recognise that basic constitutional concepts, such as citizenship, human rights or personhood, convey a set of normative values and express basic choices of societies which change over time. ${ }^{80}$ If this assumption is correct, essential points of reference for more specific questions of legal interpretation are less static than one might suggest and it seems that supranational rules on citizenship, migration and human rights are excellent examples to illustrate the inherent ambiguity of conceptions of personhood in EU law. From a perspective of constitutional theory, debates on the meaning and reconfiguration of such essentially contested concepts can be described as a process of jurisgenesis where the interpretation of the law interacts with contextual factors and broader societal debates. ${ }^{81}$ Union law deconstructs old conceptions of nation-state membership or alienage and, yet, it is unclear how to explain the new setting positively.

Methodologically, this chapter follows an approach one may call contextually embedded doctrinal constructivism, since it assumes, in contrast to US-style legal realism, that legal concepts can have a semi-autonomous significance and that academia may contribute to their rationalisation. ${ }^{82}$ Corresponding analyses are based on a reconstruction of the case-law and its doctrinal foundations, thereby ideally supporting a better understanding of the systemic coherence of the law and its internal inconsistencies. ${ }^{83}$ Doing so assumes that doctrinal arguments

\footnotetext{
79 Recital 2 (emphasis added).

80 See for the US context L Bosniak, 'Persons and Citizens in Constitutional Thought' (2010) 8 International Journal of Constitutional Law 9-29; and generally RM Cover, 'Foreword: Nomos and Narrative' (1983) 97 Harvard Law Review 4, 11-44.

81 See S Benhabib, 'Claiming Rights across Borders: International Human Rights and Democratic Sovereignty' (2009) 103 American Political Science Review 691, 697-99; and FI Michelman, 'Law's Republic' (1988) 97 Yale Law Journal 1493-537.

82 See G Beck, The Legal Reasoning of the Court of Justice of the EU (Oxford, Hart Publishing, 2012); and T Horsley, 'Reflections on the Role of the Court of Justice as the "Motor" of European Integration' (2013) 50 Common Market Law Review 931, 934-54.

83 See R van Gestel and HW Micklitz, 'Why Methods Matter in European Legal Scholarship' (2014) 20 European Law Journal 292-316.
} 
and constraints should be taken seriously in a discursive community involving academics in the constant reconstruction of the legal infrastructure. ${ }^{84}$ This focus on intra-legal arguments falls short of a critical analysis of legal developments from an external standpoint, while acknowledging that abstract legal concepts, such as citizenship or human rights, require a broader constitutional outlook in a process Armin von Bogdandy has aptly described as a doctrinal argument about constitutional principles. ${ }^{85}$ Their inherent openness allows for connections with other disciplines even if such feedback loops will never result in the simple transfer of extra-legal arguments into doctrinal reasoning. ${ }^{86}$ This chapter follows this approach by extrapolating the constitutional infrastructure guiding the interaction of the diverse sets of rules on free movement, Union citizenship, human rights and migration law.

\section{A. The Puzzle}

The example of labour migration illustrates a conceptual puzzle at the heart of the European project: there does not seem to be a major difference, from a sociological point of view, between a Ukrainian national and Greek national working in Germany. They live in a country of which they do not possess its nationality, are faced with a foreign language and may be confronted with comparable challenges of equal treatment and social integration. Nonetheless, their legal status differs quite fundamentally. While the Greek national qualifies as a Union citizen under Article 20(1) TFEU (Treaty on the Functioning of the European Union) and benefits, therefore, from an individual right with constitutional status to transnational mobility as a migrant worker in accordance with Article 45 TFEU, the Ukrainian national must be classified as a third-country national from the perspective of the EU Treaties. Such foreigners are not covered by the fundamental freedoms, although they may invoke statutory guarantees in secondary legislation under the conditions set out by the legislature as well as, possibly, human rights in the EU Charter, which, in the field of labour migration, reaffirms the principled distinction described above. ${ }^{87}$

In order to resolve the puzzle it is important to understand that the free movement of Union citizens is nowadays conceptualised as being intricately linked to Union citizenship, whose contours and finalité may remain vague, ${ }^{88}$

${ }^{84}$ See M Kumm, 'On the Past and Future of European Constitutional Scholarship' (2009) 7 International Journal of Constitutional Law 401, 406-11.

85 See A von Bogdandy, 'Founding Principles of EU Law: A Theoretical and Doctrinal Sketch' (2010) 16 European Law Journal 95, 98-100.

86 See von Bogdandy, ibid, 100-04.

87 Contrast Art 15(2) and (3) EU Charter.

88 See D Thym, 'Citizens and Foreigners in EU Law. Migration Law and Its Cosmopolitan Outlook' (2016) 22 European Law Journal s 1.3 (forthcoming). 
but which nonetheless embraces free movement as an essential guarantee. The EU legislature expressed the desire to remedy, in light of the overarching concept of Union citizenship, the 'sector-by-sector, piecemeal approach to the right of free movement' 89 and the ECJ emphasised that a 'particularly restrictive interpretation'90 of national restrictions to the free movement of workers was required by the introduction of Union citizenship. It became the fixed star guiding the interpretation of different settings in line with the ECJ's principled assertion that the new concept 'is destined to be the fundamental status of nationals of the Member States. ${ }^{91}$

The use of the term 'status' in this quotation deserves our attention. It emphasises at a semantic level that Union citizenship should not be confused with universal personhood. In line with the long tradition of the term 'status' in Roman law and civil law jurisdictions in continental Europe described above, it should be read as designating a collection of rights for specific purposes which may overlap with other statuses persons may hold in parallel. ${ }^{92}$ Unfortunately, it is not crystal clear how the concept of 'status' found its way into the case-law. Advocate General La Pergola is widely credited for having introduced it in his opinion in Martinez Sala, although closer inspection of the original Italian language version advises caution $^{93}$ (La Pergola would have been a plausible source given his background as a professor of constitutional law in a continental jurisdiction).${ }^{94}$ Advocate General Alber similarly used the term in his opinion in Grzelczyk, albeit in a rather mundane manner and without much conceptual overtones. ${ }^{95}$

It is therefore difficult to verify whether the use of the term 'fundamental status' by the ECJ in relation to Union citizenship was meant to continue the tradition of Roman law and civil law jurisdictions. However, such a reading could rather well explain that the original citation was not limited to a simple invocation of fundamental status, but rather as the ECJ states it 'enabl[ed] those who find themselves in the same situation to enjoy the same treatment in law irrespective of their nationality, subject to such exceptions as are expressly provided for. ${ }^{96}$ This suits the relativity of the concept of status in Roman and civil law where it is often

\footnotetext{
89 Recital 4 Dir 2004/38/EC [2004] OJ L158/77.

90 Cases C-482/01 \& C-493/01 Orfanopoulos \& Olivieri, EU:C:2004:262, para 65.

91 Case C-184/99 Grzelczyk, EU:C:2001:458, para 31 (emphasis added).

92 See above s II.A.

93 AG A La Pergola, Case C-85/96, Martínez Sala, EU:C:1997:335, para 18 employed the term 'la situazione giuridica di base' (not: 'lo status fondamentale dei cittadini degli Stati membri', like the ECJ in Grzelczyk); similarly, the French ('situation juridique de base') and German ('grundlegende Rechtsstellung') translation-in contrast to the English language version ('fundamental legal status').

94 See his CV at http://curia.europa.eu/jcms/jcms/Jo2_7014.

95 See AG S Alber, Grzelczyk, Case C-184/99, EU:C:2000:518, para 52, which is complemented by multiple other uses in a rather unspecific manner ('status of student'); altogether, the term 'status' is used no less than 10 times in the original German language version, 12 times in the French translation and no less than 55 times in the English translation, which employs it for describing the characteristics of the worker as well; Alber studied law, but worked as a politician and civil servant thereafter, see http://curia.europa.eu/jcms/jcms/Jo2_7014.

96 ECJ (n 91) para 31.
} 
applied to rather specific situations such as the status of a person under family law. Against this background, the fundamental status formula would concern, essentially, equal treatment in situations of (legal) residence in another Member Stateno more, no less. Arguably, some academic observers without a background in continental European civil law read too much into the use of the term 'status'. Of course, the somewhat revolutionary outcome of the Grzelczyk case indicated that the new formula was meant to pave the way for great changes, but the terminology used could also be conceived as a rather sober description of existing rights.

For the purposes of our analysis, this linkage between traditional debates in continental civil law and contemporary discussions over Union citizenship justifies two conclusions. First, the description of Union citizenship as a 'fundamental status' in a number of different scenarios covered by Union law should not necessarily be confused with essential notions of personhood or dignity; in other words, it arguably conflates two distinct categories. ${ }^{97}$ Secondly, the classification of citizenship as a status fits well into the broader constitutional landscape, since the introduction of Union citizenship and of rules on third-country nationals into the EU legal order were parallel developments. In order to disentangle the resulting citizenship-foreigner-cleavage it is necessary to explain the second category.

\section{B. Three Academic Reconstructions}

In nation states, rules on citizenship often appear as the legal reflection of quasinatural phenomena. They often build upon strong and historically contingent identities as well as an enhanced degree of social and political cohesion, which disguise the element of reconstruction inherent in the concept of collective identities in any constitutional setting, also at the level of the nation state. ${ }^{98}$ In the European Union, this is not the case. The Treaty of Maastricht may have introduced rules on 'citizenship' which were taken up by the Court in judgments filling the Treaty regime with doctrinal substance. Yet, this legal and doctrinal relevance hardly reflects an existing real-life citizenship based on shared identities. Most social scientists agree that the legal construction of Union citizenship does not coincide with the social construction of European identity. ${ }^{99}$ In the words of the German constitutional court: 'In this sense, the citizenship of the Union is nothing which culturally or normatively precedes the EU Treaties.' ${ }^{100}$

\footnotetext{
97 cf the critique by C O’Brien, 'I Trade, Therefore I Am: Legal personhood in the European Union' (2013) 50 Common Market Law Review 1643-84.

98 See D Kostakopoulou, The Future Governance of Citizenship (Cambridge, Cambridge University Press, 2008) ch 2; and B Anderson, Imagined Communities: Reflections on the Origin and Spread of Nationalism (London, Verso, 1991).

99 cf G Delanty, 'European Citizenship: A Critical Assessment' (2007) 11 Citizenship Studies 63-72.

100 Bundesverfassungsgericht (BVerfG), Judgment of 30 June 2009, Case 2 BvE 2/08 et al, Treaty of Lisbon, para 348 (own translation).
} 
If the latter is correct, it complicates the resolution of the citizenship-foreignercleavage. To be sure, legal rules on personhood, citizenship and foreigners are always a construction and the same applies to political identities and social solidarity. But in the EU, the connection between legal rules and social facts is weak at best. In a certain way, EU citizenship pretends to be more than it is. ${ }^{101}$ It largely lacks the substratum of common identities and social solidarity which define the nation state; Union citizenship is primarily a virtual, legal reality. Against this background, our academic analysis of the citizenship-personhood-cleavage has three major options.

First, we could deconstruct Union citizenship as an 'empty gesture', a sort of 'cynical public relations exercise' on the part of the High Contracting Parties ${ }^{102}$ a misnomer which should better be forgotten. It seems to me that this is to a certain extent at least a realistic option, insofar as it reminds academic observers of the limits of political and social imagination legal developments are capable of bringing about. ${ }^{103}$ They participate in the constant reconstruction of identities, but cannot change them single-handedly; they need to be embedded into social structures and political life. Recent cases, such as Dano, show that there are limits in what abstract notions such as citizenship can achieve at this juncture. ${ }^{104}$

Secondly, one may emphasise the empirical situation and present the European project as a prototype for transnational governance which detaches citizenship from the nation state and recognises various forms of post- or transnational membership. On the basis of legal developments in Europe, Yasemin Soysal famously argued 20 years ago that universal personhood was about to replace state citizenship as the basis for rights. ${ }^{105}$ From this standpoint, Union citizenship would present a model of rules which third-country nationals should follow in a similar way as some international lawyers and political theorists, most of whom are from continental Europe, present EU integration as a model for and first step towards global constitutionalism. ${ }^{106}$

Approaching the citizenship-personhood-cleavage from this position, the distinction between citizens and third-country nationals in positive EU law appears

\footnotetext{
101 For a critical assessment see U Haltern, 'Pathos and Patina' (2003) 9 European Law Journal 14, 26-32; and J Přibán̆, 'The Juridification of Identity, Its Limitations and the Search of EU Democratic Politics' (2009) 16 Constellations 44-58.

102 cf JHH Weiler, 'European Citizenship and Human Rights' in JA Winter et al (eds), Reforming the Treaty on European Union (The Hague, TMC Asser, 1996) 57, 68, 73.

103 See D Thym, 'Frontiers of EU Citizenship. Three Trajectories and their Methodological Foundations' in D Kochenov (ed), EU Citizenship and Federalism. The Role of Rights (Cambridge, Cambridge University Press, 2016) s 3 (forthcoming).

104 See S Barbou des Places, 'La cohérence du droit de la libre circulation des personnes à l'épreuve de la mobilité des indigents' (2015) Revue trimestrielle de droit européen 133, 145; and Thym (n 77) 259-60.

105 See Y Soysal, Limits of Citizenship (Chicago, University of Chicago Press, 1994) chs 7-9.

106 See the overview by M Koskenniemi, 'The Fate of Public International Law' (2007) 80 Modern Law Review 1, 15-19; and J Habermas, Die postnationale Konstellation (Frankfurt/Main, Suhrkamp, 1998).
} 
arbitrary-at least from a conceptual perspective. If the EU is in essence about overcoming the nation state, it should not make a difference whether a worker applying for a job in Germany comes from Ukraine or Greece. In academic debates, corresponding arguments are widespread and present themselves in two forms. Many explore the doctrinal potential of Treaty law or secondary legislation for status approximation. ${ }^{107}$ Others move beyond doctrinal hermeneutics and criticise the status quo from an extra-legal standpoint. They warn against 'European Apartheid' or decry the spread of social control mechanisms. ${ }^{108}$ Both arguments share the assumption that the citizenship-personhood-cleavage that can be found in positive Union law is an aberration contradicting the conceptual underpinning of rules on citizenship and broader objectives of EU integration and should therefore be minimised as far as possible.

Thirdly, one may try to reconstruct the distinction between citizens and foreigners from within the legal order in line with the methodological underpinnings of a contextually embedded doctrinal constructivism described above. One starting-point for doing so is the observation that our analytical choice is not limited to the binary juxtaposition of the legally sovereign and culturally homogeneous nation state on the one hand and an extensive and deep moral and institutional universalism on the other hand. ${ }^{109}$ There is room for intermediate solutions between sovereign statehood and thick universalism. On this basis, one may emphasise that the status of third-country nationals can be given an autonomous constitutional reading if we detach its analysis from a comparison with Union citizenship. That is what I mean by deciphering personhood as the default position of Union law which comes to the fore ex negativo when we leave aside rules which are specific to the fundamental status of Union citizenship.

Doing so does not leave non-citizens without legal protection, since they can invoke human rights. Human rights allow critics of the status quo to articulate their concerns within the framework of the EU Treaties ${ }^{110}$ _even if human rights are conceptually and doctrinally more flexible than citizens' rights, since they allow for the accommodation of countervailing public policy considerations, which emanate for particularistic self-government. ${ }^{111} \mathrm{I}$ do not claim that this

\footnotetext{
107 cf Groenendijk (n 44) 313-35; and A Wiesbrock, 'Granting Citizenship-related Rights to ThirdCountry Nationals' (2012) 14 European Journal of Migration and Law 63-94.

108 See, by way of example, D Acosta Arcarazo and J Martire, 'Trapped in the Lobby: Europe's Revolving Doors and the Other as Xenos' (2014) 39 EL Rev 362-79; and, more generally, G Agamben, 'Au-delà des droits de l'homme' La Libération of 9/10 June 1993.

109 See U Beck, Cosmopolitan Vision (Cambridge, Polity, 2006) ch 1; and S Benhabib, The Rights of Others: Aliens, Residents, and Citizens (Cambridge, Cambridge University Press, 2004) ch 4.

110 See M Kumm, 'The Idea of Socratic Contestation and the Right to Justification' (2010) 4 Law \& Ethics of Human Rights 141-75; and S Besson, 'Deliberative Demoi-cracy in the European Union' in ibid and JL Martí (eds), Deliberative Democracy and its Discontents (Farnham, Ashgate, 2006) 181, 193-204.

111 See D Thym, 'EU Migration Policy and its Constitutional Rationale' (2013) 50 Common Market Law Review 709, 718-21.
} 
model supports easy solutions: individual cases will always be contested. All I say is that at an abstract level of analysis the constitutional infrastructure is intact. We can explain the status of third-country nationals without necessarily connecting it to Union citizenship. It does not deny the legal and moral significance of personhood to distinguish the citizens' rights of some from the human rights of all. This account is not universalist in a thick sense, but it is not statist either. It presents an intermediate solution, which one may call the 'cosmopolitan outlook' underlying EU law ${ }^{112}$ _although this description can certainly be contested. That is what I perceive to be the default position of personhood in EU law which can be construed positively independent of the citizenship status on the basis of human rights. It would require substantive analyses of EU immigration and asylum law to identify how far the EU legal order recognises basic notions of personhood in specific scenarios of transnational mobility.

\section{Conclusion}

As a supranational legal order, EU law governs only certain aspects of human behaviour and its perspective is necessarily a partial one. Having emerged as a project of economic integration, Union law did not comprise an explicit concept of personhood from the beginning and it continues to be fragmented into different policy fields. This chapter therefore concentrated on substantive rules in the EU Treaties with a particular focus on free movement, Union citizenship, human rights and migration. Such an approach follows the conclusion that abstract notions of 'legal personhood', such as the human right to equal personality before the law enshrined in Article 16 ICCPR, have little bearing in practice beyond a number of borderline scenarios such as the beginning of birth or extraterritorial state action. The recognition of equal personhood may appear self-evident from today's perspective, but it was the outcome of extensive debates in legal practice and philosophy building on the traditional notion of 'status' characterising relations of individuals with society, which had defined debates in civil law jurisdictions which follow the tradition of Roman law for centuries.

In EU law, the concept of individual and human rights lies at the heart of a project building upon integration through law, since it was developed by the ECJ to guarantee the effet utile of Union law, inter alia by engaging individuals in its enforcement. Notwithstanding this functional pedigree, the concept of individual rights can develop a life of its own when individuals promote their agenda via Union law. Such dynamism is possible, in particular when the interests of individuals coincide with the EU's objectives, but remains subject to structural caveats such as restrictive standing rights before the Court of Justice. An assessment of

112 See Thym (n 88) s 4 (forthcoming); and Thym (n 111) 725-35. 
underlying notions of legal personhood should also consider substantive guarantees. This chapter did so by extrapolating two distinct categories of the rightbearer which evolved gradually and define rules on free movement and migration nowadays: Union citizens and third-country nationals.

Basic constitutional concepts such as citizenship and human rights are not confined to legal debates, but convey normative values which can change over time. Against this background, the 'citizenship-foreigner-cleavage' on a distinct set of rules for Union citizens and third-country nationals in positive EU law is in need of explanation. The resolution of this puzzle should recognise that specific rules for Union citizens are conceived, from today's perspective, as the expression of a 'fundamental status' - a description which should not be confused with essential notions of personhood or dignity in light of the traditional meaning of statuses designating a collection of special rights in continental civil law. By contrast, the default position on personhood in EU law comes to the fore ex negativo when we leave aside citizens' rights and focus on third-country nationals. In this respect, the entry into force of the Treaty of Lisbon reaffirmed an intermediate solution which falls short of citizenship but comprises individual guarantees whose contours remain contested. In that respect, the notion of personhood underlying EU migration law is very much in flux. 